УДК 343.235

DOI https://doi.org/10.32849/2663-5313/2020.8.37

Олена Свдокімова,

канд. юрид. наук, дочент,

доцент кафедри кримінального права № 1

Начіонального юридичного університету імені Ярослава Мудрого

\title{
КРИМІНАЛЬНА ВІДПОВІДАЛЬНІСТЬ ЗА ПОВТОРНІСТЬ КРИМІНАЛЬНИХ ПРОСТУПКІВ
}

Стаття присвячена аналізу змін до ст. 309 Кримінального кодексу України, яка передбачає відповідальність за незаконне виробничтво, виготовлення, придбання, зберігання, перевезення чи пересилання наркотичних засобів, психотропних речовин або їх аналогів без мети збуту. Законом України від 22 листопада 2018 року № 2617-VIII діяння, передбачене ч. $1 \mathrm{~cm} .309$ КК, було віднесене до категорії кримінальних проступків. Також зазнала змін ч. 2 cm. 309 КК. Кваліфікуючу ознаку у виді «вчинення повторно злочину, передбаченого ст. 309 КК, чи злочинів, передбачених статтями 307, 308, 310 , 317 КК» було замінено на нову ознаку, а саме: «ті самі дії, вчинені протягом року після засудження за иією статтею». У змісті даної ознаки можна виділити об'єктивні та суб'єктивні характеристики. Об'єктивні - вчинення двох або більше діянь, передбачених ст. 309 КК. Суб'єктивні: 1) засудження особи за вчинення діяння, передбаченого $\mathrm{cm}$. $309 \mathrm{KK}$; 2) вчинення нового тотожного діяння; 3) вчинення особою нового кримінального правопорушення протягом року з моменту засудження. У зв'язку з иим дану ознаку можна визнати новою самостійною формою множинності кримінальних проступків. Проте дана нова форма множинності суттєво відрізняється від усталених у кримінальному праві форм множинності - повторності та рецидиву кримінальних правопорущень. Зважаючи на те, що санкиія ч. $1 \mathrm{~cm} .309$ КК передбачає покарання у виді штрафу, виправних робіт, арешту, обмеження волі, звертається увага на те, що на практииі можуть виникнути ситуаиії, за яких, незважаючи на те що особа відбула покарання та не визнається судимою, вчинене нею діяння все одно матиме кримінально-правове значення. Також може виникнути інша ситуачія: якщо особа продовжує відбувати покарання за ст. 309 КК та знов вчиняє те саме кримінальне правопорушення, врахувати цей факт при кваліфікаціӥ суд не зможе, якщо з моменту засудження минув один рік. Зазначається, що такий зміст даної кваліфікуючої ознаки не відповідає усталеному погляду на сочіально-правове значення множинності правопорушень, у зв'язку з чим наголошується на необхідності ї̈ подальшого наукового дослідження та законодавчого вдосконалення.

Ключові слова: кримінальний проступок, повторність, засудження, кримінальне правопорушення, множинність.

Постановка проблеми. У зв'язку з прийняттям Закону України від 22 листопада 2018 року № 2617-VIII «Про внесення змін до деяких законодавчих актів України щодо спрощення досудового розслідування окремих категорій кримінальних правопорушень» [1] у Кримінальному кодексі України (далі - КК) поняття «злочинність» замінене на термін «кримінальна протиправність», поняття «злочин» - на «кримінальне правопорушення», під яким відповідно до нової редакції ст. 11 КК розуміється передбачене КК суспільно небезпечне винне діяння (дія або бездіяльність), вчинене суб'єктом кримінального правопорушення. При цьому термін «кримінальне правопорушення» $є$ узагальнюючим, який охоплює собою два види кримінальних деліктів - кримінальний проступок та злочин. Відповідно до нової редакції ч. 2 ст. 12 КК кримінальним проступком визнається діяння, за вчинення якого перед- бачене основне покарання у виді штрафу в розмірі не більше трьох тисяч неоподатковуваних мінімумів доходів громадян або інше покарання, не пов'язане з позбавленням волі.

Проблема реформування вітчизняного законодавства з метою запровадження інституту кримінального проступку неодноразово порушувалася в науковій літературі та досліджувалася багатьма вченими, серед яких: П. П. Андрушко, Ю. В. Баулін, В. І. Борисов, О. О. Дудоров, Т. А. Денисова, Л. М. Демидова, Ю. А. Пономаренко, В. О. Навроцький, В. Я. Тацій, В. І. Тютюгін, В. О. Туляков, П. Л. Фріс, М. І. Хавронюк та інші. При цьому серед наукової спільноти були як прихильники, так і противники проведення цієї реформації. Втім, на думку законодавця, дана реформа вітчизняного законодавства мала сприяти спрощенню порядку досудового розслідування кримінальних правопорушень невеликої тяжкості, а також змен- 
шенню навантаження на органи досудового слідства. Однак, незважаючи на певні позитивні моменти цих змін, деякі нововведення викликають певні зауваження та потребують подальшого наукового аналізу та законодавчого вдосконалення.

Метою статті є системний аналіз змін, внесених до КК, та розробка пропозицій щодо вдосконалення окремих кримінально-правових положень, зокрема, в частині кримінальної відповідальності у разі наявності повторності кримінальних проступків.

Виклад основного матеріалу. Однією із законодавчих новел, яка потребує свого наукового вивчення, є кваліфікуюча ознака незаконного виробництва, виготовлення, придбання, зберігання, перевезення чи пересилання наркотичних засобів, психотропних речовин або їх аналогів без мети збуту, яка відповідно до Закону України від 22 листопада 2018 року № 2617-VIII була введена до ч. 2 ст. 309 КК. У попередній редакції ч. 2 ст. 309 КК до кваліфікуючих ознак даного делікту належало вчинення повторно злочину, передбаченого ст. 309 КК чи злочинів, передбачених статтями $307,308,310$, 317 КК. Після змін у ч. 2 ст. 309 КК нині передбачається: «ті самі діï, вчинені протягом року після засудження за чією статтею». Таким чином, у зв'язку з реформою кваліфікуюча ознака ч. 2 ст. 309 КК у виді повторності однорідних діянь, передбачених статтями $307,308,310,317$ КК, та повторності тотожних кримінальних правопорушень, передбачених ст. 309 КК, не пов'язаних із засудженням, була замінена новою, до того ж певним чином новою для вітчизняного кримінального права ознакою.

Загалом, вчинення того ж самого діяння протягом одного року з моменту засудження може свідчити про наявність у поведінці особи множинності кримінальних правопорушень, під якою у правовій літературі визнається вчинення особою (групою осіб) 2-х або більше діянь, кожне з яких передбачене у КК як самостійний склад кримінального правопорушення [2, с. 523]. Втім, це на перший погляд. Більш детальний аналіз цієї кваліфікуючої ознаки свідчить про те, що її зміст лише частково відповідає традиційному розумінню у науці кримінального права та кримінальному законодавстві множинності кримінальних правопорушень.

Так, в ознаці «вчинення того ж самого діяння протягом року 3 моменту засудження» (ч. 2 ст. 309 КК) можна виділити кількісні та якісні характеристики. До кількісних належить факт вчинення двох або більше діянь, передбачених ст. 309 КК. Саме ця властивість цієї ознаки наближує їі до поняття множинності кримінальних правопорушень. Що ж стосується якісної їі властивості, то вона характеризується сукупністю таких елементів: 1) засудження особи за вчинення діяння, передбаченого ст. 309 КК; 2) вчинення нового тотожного діяння, тобто діяння, відповідальність за яке передбачена будь-якою частиною ст. 309 КК 3) вчинення особою нового кримінального правопорушення протягом року з моменту набуття обвинувальним вироком законної сили за попередне правопорушення. Отже, за характеристикою «вчинення того ж самого діяння» дана кваліфікуюча ознака збігається з повторністю, а за фактом попереднього засудження - 3 рецидивом кримінальних правопорушень. Водночас остання сутнісна властивість цієї ознаки дозволяє визнати за певних умов «вчинення особою діяння, передбаченого ст. 309 КК, протягом року 3 моменту засудження за ст. 309 КК» самостійним видом множинності кримінальних правопорушень, відмінним від повторності (ст. 32 КК) та рецидиву (ст. 34 КК) кримінальних правопорушень.

Відповідно до змін, внесених цим Законом, незаконне виробництво, виготовлення, придбання, зберігання, перевезення чи пересилання наркотичних засобів, психотропних речовин або їх аналогів без мети збуту (ч. 1 ст. 309 КК) віднесено до категорії кримінальних проступків. А це означає, що у разі засудження за ч. 1 ст. 309 КК з моменту відбуття покарання особа буде вважатися такою, що не має судимості (п. $2^{1}$ ст. 89 КК). Водночас санкція ч. 1 ст. 309 КК передбачає такі види покарання: штраф від однієї тисячі до трьох тисяч неоподатковуваних мінімумів доходів громадян, або виправні роботи на строк до двох років, або арешт на строк до шести місяців, або обмеження волі на строк до п'яти років. У зв'язку з таким змістом санкції ч. 1 ст. 309 КК на практиці можуть виникнути такі проблемні ситуації.

Перша пов'язана із засудженням особи за ч. 1 ст. 309 КК до покарання, строк якого не перевищує одного року, тобто до штрафу, арешту, виправних робіт від 6 місяців до 1 року. Наприклад, особа, яка за ч. 1 ст. 309 КК була засуджена до штрафу, через 6 місяців після засудження знов незаконно виготовляє наркотичний засіб без мети збуту. Відповідно до ст. 26 Кримінально-виконавчого кодексу України засуджений зобов'язаний сплатити штраф у місячний строк після набрання вироком суду законної сили, за винятком, якщо йому не була надана розстрочка сплати штрафу згідно з ч. 4 ст. 53 КК. Відповідно до п. $2^{1}$ ст. 89 КК особи, засудженні за вчи- 
нення кримінального проступку, після відбуття покарання вважаються такими, що не мають судимості. Отже, за наведених умов вчинення наступного кримінального проступку, передбаченого ч. 1 ст. 309 КК, не містить ознак повторності або рецидиву кримінальних правопорушень, бо штраф, призначений за раніше вчинений проступок, вже був сплачений, а отже судимість була погашена. Таким чином, виходячи з положень статей 32, 34 та ч. 1 і 2 ст. 88 КК, раніше вчинене діяння вже має втратити своє юридичне значення. Як наголошує Верховний Суд, «припинення судимості анулюе всі кримінально-правові та загальноправові наслідки засудження та призначення покарання. Особа, судимість якої погашена або знята, вважається такою, яка раніше злочину не вчиняла, покарання не відбувала. Вона не зобов'язана будь-де вказувати вчинення нею в минулому злочину та призначення за нього покарання, не повинна відчувати жодних негативних наслідків колишньої судимості» [3]. Втім, за логікою законодавця, у наведеному прикладі попереднє діяння не втрачає свого юридичного значення, у зв'язку з чим знов вчинене тотожне діяння має кваліфікуватися за ч. 2 ст. 309 КК за ознакою «вчинення того самого діяння протягом року після засудження». Однак на підставі чого попереднє діяння продовжує зберігати своє кримінально-правове значення? Виходячи 3 положень ч. 2 ст. 309 КК, можна зробити висновок, що у зв'язку з останніми змінами до КК традиційне для кримінального права розуміння правового значення попереднього правопорушення не поширюється на кримінальні проступки, бо, незважаючи відбуття покарання та припинення судимості, все одно раніше вчинене нею діяння продовжує мати кримінально-правове значення протягом року (ч. 2 ст. 309 КК). Тобто у даному випадку відсутність судимості не виключає негативних кримінально-правових наслідків для особи, яка вчинила даний кримінальний проступок. У цьому аспекті досліджувана кваліфікуюча ознака відрізняється від повторності (ст. 32 КК) та рецидиву (ст. 34 КК) кримінальних правопорушень. Дана ознака охоплює собою більш широке коло випадків повторного вчинення кримінального правопорушення, ніж види множинності, передбачені в Загальній частині КК, бо включає також тотожні діяння, які на відміну від повторності та рецидиву були вчиненні після відбуття покарання та припинення судимості.

y такому законодавчому підході до визначення кримінально-правових наслідків повторного вчинення кримінального проступку, передбаченого ст. 309 КК, вбачається вплив особливостей правового регулювання відповідальності за вчинення адміністративних діянь. Так, відповідно до п. 2 ст. 35 Кодексу України про адміністративні правопорушення обтяжуючою обставиною визнається «повторне протягом року вчинення однорідного правопорушення, за яке особу вже було піддано адміністративному стягненню». Вважаємо, що посилення адміністративної відповідальності за повторне вчинення адміністративного делікту протягом року після того, як особа була піддана адміністративному стягненню, зумовлено прагненням законодавця закріпити виправний ефект адміністративних стягнень, бо їх строки (за винятком позбавлення спеціального права, наданого даному громадянинові, позбавлення права обіймати певні посади або займатися певною діяльністю (ст. 30 КУ ПАП) не перевищують одного року, а у разі притягнення до адміністративної відповідальності стан судимості не виникає. Що ж стосується кримінального права, то підхід, вибраний законодавцем у ч. 2 ст. 309 КК, не узгоджується з нормами інших правових інститутів.

Досліджувану законодавчу новацію можна виправдати прагненням законодавця попередити продовження вчинення кримінального проступку, передбаченого ч. 1 ст. 309 КК, після засудження та відбуття покарання. Проте все одно, якщо цей підхід i можна за певних умов визнати допустимим, то тільки для окремих випадків, а саме засудження за ст. 309 КК до покарання у виді штрафу, арешту або виправних робіт, тобто видів покарання, строк виконання яких не перевищує 1 року. Проте санкція ч. 1 ст. 309 КК, крім зазначених видів покарань, передбачає й інші, а саме: виправні роботи строком до 2 років та обмеження волі на строк до 5 років. Тобто види покарань, які можуть призначатися на строк, який значно перевищує однорічний термін, визначений законом у ч. 2 ст. 309 КК. Якраз у разі вчинення нового кримінального проступку, передбаченого ч. 1 ст. 309 КК, протягом року після засудження за ч. 1 ст. 309 КК до виправних робіт або обмеження волі на строк понад 1 рік і виникає інша правова ситуація. Припустимо, що за ч.1 ст. 309 КК особа була засуджена до виправних робіт на 2 роки. Якщо дана особа під час відбування виправних робіт протягом року з моменту засудження знову вчинить діяння, передбачене ч. 1 ст. 309 КК, її дії мають кваліфікуватися за ч. 2 ст. 309 КК. Проте якщо вона вчинить теж саме діяння під час відбування виправних робіт у період від 1 року і 1 дня 
до 2 років з моменту засудження, то в її поведінці вже буде відсутня дана кваліфікуюча ознака і вчинене потрібно буде кваліфікувати за ч. 1 ст. 309 КК. Тобто, незважаючи на те що поведінку особи можна визнати повторністю та рецидивом кримінальних правопорушень (ст. 32, 34 КК), кваліфікувати вчинене за ч. 2 ст. 309 КК суд вже немає права. Це стосується і випадків засудження за ч. 1 ст. 309 КК до обмеження волі. Проте таке рішення законодавця не можна визнати виваженим та справедливим, бо в основі такої диференціації кримінальної відповідальності за ст. 309 КК перебуває не стільки рівень суспільної небезпечності особи у виді відсутності позитивних змін у поведінці засудженого під час відбування покарання, скільки суто формальний критерій - тривалість строку, який минув з моменту попереднього засудження. За цих умов кваліфікуюча ознака ч. 2 ст. 309 КК виявляється вужчою за повторність або рецидив кримінальних правопорушень, бо згідно з її змістом кримінальне правопорушення, передбачене ст. 309 КК, зберігає своє кримінально-правове значення лише протягом 1 року з моменту засудження, тоді як повторність, пов'язана із засудженням, може мати місце у разі вчинення нового делікту впродовж всього строку призначеного покарання і до моменту погашення чи зняття судимості за його вчинення (ч. 4 ст. 32 КК). У зв'язку 3 цим можна констатувати, що зміст даної кваліфікуючої ознаки не відповідає усталеному у науці кримінального права погляду на значення множинності кримінальних правопорушень, згідно з яким її наявність свідчить насамперед про підвищений ступінь суспільної небезпеки як винної особи, так і вчиненого ним діяння.

На думку В. I. Тютюгіна та I. О. Зінченко, множинність має подвійну правову природу. 3 одного боку, вчинення декількох кримінальних правопорушень призводить до заподіяння шкоди більш широкому колу суспільних відносин, що призводить до підвищення ступеня суспільної небезпеки вчиненого діяння за рахунок збільшення розміру спричиненої шкоди. 3 іншого боку, як правило, свідчить про стійку антисоціальну спрямованість особи винного та негативно впливає на окремих нестійких членів суспільства, створює ілюзію безкарності, скасовує страх перед покаранням, породжує правовий нігілізм і зневагу до права $[5$, с. 17,18$]$. Саме тому законодавча новація, згідно з якою рівень суспільної небезпечності діяння, передбаченого ст. 309 КК, підвищується лише у разі повторного вчинення того ж самого діяння, але протягом року з моменту засу- дження (ч. 2 ст. 309 КК), не відповідає кримінально-правовому значенню множинності кримінальних правопорушень. До речі, цей недолік кримінально-правової регламентації може негативно вплинути на процес індивідуалізації кримінальної відповідальності за неодноразове вчинення кримінальних проступків, передбачених ч. 1 ст. 309 КК зважаючи на те, що відповідно до чинної редакції п. 1 ч. 1 ст. 67 КК обставиною, що обтяжує покарання, виступає повторність або рецидив виключно злочинів, а не кримінальних правопорушень. Таким чином, якщо з моменту попереднього засудження минув один рік, суд повторне вчинення того ж самого кримінального проступку, передбаченого ч. 1 ст. 309 КК, протягом строку відбування покарання за раніше вчинений не зможе врахувати ні під час кваліфікації, ні під час призначення більш суворого покарання в межах санкції ч. 1 ст. 309 КК.

Нову редакцію кваліфікуючої ознаки ч. 2 ст. 309 КК можна пояснити тим, що діяння, передбачене ч. 1 ст. 309 КК, законодавцем було віднесено до категорії кримінальних проступків. Втім, у ст. 309 КК встановлена кримінальна відповідальність не тільки за кримінальні проступки, а й за злочини (частини 2 і 3 ст. 309 КК), у тому числі за тяжкі. У свою чергу, у разі повторного вчинення особою, засудженою за ч. 3 ст. 309 КК, того ж самого тяжкого злочину виникає колізія положень Загальної та Особливої частини КК. Згідно з положеннями Особливої частини КК повторне вчинення злочинів, передбачених ст. 309 КК, враховується тільки протягом однорічного строку 3 дня набуття обвинувальним вироком законної сили за попередне правопорушення, тоді як у ч. 4 ст. 32 КК зазначено, що повторність злочинів має місце протягом усього строку відбування покарання та погашення судимості Водночас не можна не враховувати того, що неодноразове вчинення тих самих злочинів - це не тільки юридичне поняття, але й небажане соціальне явище, яке негативно характеризує особу винного та свідчить про підвищену суспільну небезпеку особи, ступінь деформації її правосвідомості та певну злочинну звичку $[6$, с. 30; 7,126$]$. Тому, такий підхід законодавця до правової регламентації повторного вчинення злочинів, передбачених ч. 2 та 3 ст. 309 КК, зважаючи на рівень та темпи поширення наркоманії в Україні, важко визнати виправданим та доцільним.

\section{Висновки}

Безумовно, поява кримінального проступку у кримінальному законодавстві України вимагає переосмислення та впро- 
вадження нових підходів до визначення кримінально-правових наслідків його вчинення. Оскільки судимість за вчинення кримінального проступку погашається самим фактом відбуття покарання, то закріплення виправного ефекту призначеного покарання та утримання від повторного вчинення кримінальних проступків породжує необхідність у розробці та впровадженні нових дієвих превентивних кримінально-правових заходів. Таким заходом, на думку законодавця, мала би стати кваліфікуюча ознака, передбачена у ч. 2 ст. 309 КК, у виді «вчинення того ж самого діяння протягом року 3 моменту засудження». Однак аналіз цієі кваліфікуючої ознаки крізь призму інших кримінально-правових норм свідчить, що внаслідок цієї реформи у кримінальному законодавстві з'явився новий вид множинності кримінальних правопорушень, зміст якого не повною мірою узгоджується з традиційними для кримінального права розумінням правового значення множинності та ii формами: повторністю та рецидивом. Саме тому, перед тим як впроваджувати дану ознаку до ч. 2 ст. 309 КК, доцільно було врахувати насамперед особливості конструкції санкції ч. 1 ст. 309 КК, а також те, що у ст. 309 КК передбачена кримінальна відповідальність не тільки за вчинення кримінальних проступків (ч. 1 ст. 309 КК), а й злочинів (частині 2, 3 ст. 309 КК). Також, зважаючи на те що «вчинення того ж самого діяння протя- гом року з моменту засудження» являє собою певний прояв множинності кримінальних проступків у поведінці особи, доцільно було спочатку узгодити зміст даної ознаки з традиційними формами множинності кримінальних правопорушень шляхом внесення відповідних змін та доповнень до Розділу VII Загальної частини КК.

\section{Список використаних джерел:}

1. Про внесення змін до деяких законодавчих актів України щодо спрощення досудового розслідування окремих категорій кримінальних правопорушень : Закон України 22.11.2018 № 2617-VIII / Верховна Рада Украӥни. Голос України. 2019. № 79 .

2. Велика українська юридична енциклопедія : у 20 т. Т. 17 : Кримінальне право. Харків : Право, 2017. 1064 c.

3. Постанова Верховного Суду колегії суддів Другої судової палати Касаційного кримінального суду від 27 вересня 2018 року у справі № 647/1831/15-к // Єдиний державний реєстр судових рішень. URL: http://reyestr.court.gov.ua/ Review/76945371 (дата звернення: 15.07.2020).

4. Зінченко I.О., Тютюгін В.I. Множинність злочинів: поняття, види, призначення покарання. Харків: «Фіни», 2008. 336 с

5. Малков В. П. Повторность преступлений: понятие и уголовно-правовое значение. Казань : Изд-во Казан. ун-та, 1970. 174 с.

6. Колос О. В. Повторність злочинів у кримінальному праві України. Ірпінь : УДФСУ, 2018. $304 \mathrm{c}$.

\section{Olena Yevdokimova. Criminal liability for repeated criminal infractions}

The article is devoted to the analysis of changes to Art. 309 of the Criminal code of Ukraine which provides responsibility for illegal production, production, acquisition, storage, transportation or transfer of narcotic drugs, psychotropic substances or their analogs without the purpose of sale. Law of Ukraine dated November 22, 2018 No. 2617-VIII, the actions provided for in Part 1 of Art. 309 of the Criminal Code, was classified as a criminal misconduct. Also, was changed Part 2 Art 309 of the Criminal Code. Qualified offence, in the form of "repetition of the crime under Art. 309 of the Criminal Code, or crimes provided for by Articles 307, 308, 310, 317 of the Criminal Code "was replaced with a new one, namely:" the same actions committed within a year after conviction under this article. "There are objective and subjective characteristics in the content of this feature. Objective signs are the commission of two or more acts under Art. 309 of the Criminal Code. Subjective signs are 1) the conviction of a person for committing an act under Art. 309 of the Criminal Code; 2) committing a new identical act; 3) a person commits a new criminal offense within a year from the moment of conviction. In this regard, this can be considered a new independent form of multiple criminal offenses. The content of this feature allows us to attribute it to an independent form of a plurality of criminal misconducts. However, this new form of plurality differs significantly from the forms of plurality accepted in criminal law: repetition and recidivism of criminal offenses. However, the sanction of Part 1 of Art. 309 of the Criminal Code provides for punishment in the form of a fine, correctional labor, arrest, restriction of freedom. In this regard, it is noted that in practice the following situations may arise. On the one hand, despite the fact that the person has served his sentence and has an extinguished conviction, the act he has committed will still be taken into account when qualifying a new offense. Also, another situation may arise in which a person continues to serve a sentence under Art. 309 of the Criminal Code and again commits the same criminal offense, the court will not be able to take this fact into account when qualifying if one year has passed since the conviction. It is noted that such a content of this qualifying feature does not correspond to the established view of the social and legal significance of the plurality of crimes, in connection with which the need for its further scientific research and legislative improvement is emphasized.

Key words: criminal misconduct, recidivism, conviction, criminal offense, plurality. 